\title{
Relationship between coping, anxiety and depression in a Mexican sample during the onset of the COVID-19 pandemic
}

\author{
Lilia Mestas ${ }^{1}$, Fernando Gordillo ${ }^{2}$, Marco Antonio Cardoso ${ }^{1}$, José M. Arana ${ }^{3}$, Miguel Á. Pérez ${ }^{2}$ and \\ Diana Laura Colin ${ }^{1}$
}

${ }^{I}$ Facultad de Estudios Superiores Zaragoza, México, D. F., México

${ }^{2}$ Universidad Camilo José Cela, Madrid, Spain

${ }^{3}$ Universidad de Salamanca, Salamanca, Spain

\begin{abstract}
The coping strategies used during the COVID-19 pandemic could explain why certain individuals experience higher levels of anxiety and depression than others. A sample of 747 subjects completed an ad-hoc questionnaire on their habits during the pandemic, the Stress Coping Questionnaire (SCQ) focused on COVID-19; the Beck Anxiety Inventory (BAI) and the Beck Depression Inventory (BDI). High percentages of the sample recorded moderate and severe levels of anxiety (45.38\%) and depression $(32.13 \%$ ), which were higher in women. The regression model explained $30.8 \%$ and $33.5 \%$ of the variance in anxiety and depression, respectively, with the predictive capacity being greater for women than men. Passive coping strategies made up the regression model, with negative self-targeting having the greatest predictive capacity for both anxiety $\left(R^{2}=0.204\right)$ and depression $\left(R^{2}=0.215\right)$. The results reveal the need to work on reinforcing the perception of control over the situation, promoting active coping strategies.
\end{abstract}

Keywords: Emergency; stress; gender; habits; pandemic.

Relaciones entre el afrontamiento, la ansiedad y la depresión en una muestra mexicana durante el inicio de la pandemia de COVID-19

Resumen: Las estrategias de afrontamiento utilizadas durante la pandemia del COVID-19 podrían explicar por qué unas personas experimentan mayores niveles de ansiedad y depresión que otras. Una muestra de 747 sujetos completó un cuestionario adhoc sobre hábitos durante la pandemia, el cuestionario del afrontamiento del estrés (CAE) centrado en el COVID-19; y los Inventarios de ansiedad (BAI) y depresión (BDI-IA) de Beck. Se registraron altos porcentajes de la muestra con niveles moderados y graves de ansiedad (45.38\%) y depresión (32.13\%), siendo superiores en mujeres. El modelo de regresión explicó el 30.8\% y el $33.5 \%$ de la varianza en ansiedad y depresión respectivamente, siendo mayor la capacidad predictiva en mujeres que en hombres. Las estrategias de afrontamiento pasivo conformaron el modelo de regresión, siendo la autofocalización negativa la que mostró mayor capacidad predictiva tanto en ansiedad $\left(R^{2}=0.204\right)$ como en depresión $\left(R^{2}=0.215\right)$. Los resultados evidencian la necesidad de trabajar en incrementar la percepción de control de la situación, promoviendo estrategias de afrontamiento activas.

Palabras clave: Emergencia; estrés; género; hábitos; pandemia.

Recibido: 05 de diciembre 2020; aceptado: 24 de febrero 2021 Corresponding author: Fernando Gordillo, Universidad Camilo José Cela, Castillo de Alarcón, 49, 28692 Madrid, Spain. E-mail: fgordi1lo@ucjc.edu

Acknowledgments: This work was funded by a research grant awarded by the Camilo José Cela University ( $6^{\text {th }}$ UCJC Call for research Grants).

\section{Introduction}

In March 2020, the World Health Organization (WHO) declared COVID-19 to be a pandemic (WHO, 2020a). The first studies that analysed the psychological effects on people reported an increase in the intensity 
and frequency of such disorders as stress, anxiety and depression (Liu et al., 2020), caused by a fear of the unknown and uncertainty (Shigemura et al., 2020). The most common fears are related to contagion, disease, death, social isolation, and employment/income (Sandín et al., 2020). People in these kinds of situations experience a high level of stress in order to adapt and survive. This process begins when an individual detects that demands in the environment pose a threat and overwhelm their resources for coping with them. This means that understanding the type of coping strategy prevailing among people experiencing high levels of anxiety and depression in exceptional situations such as the COVID-19 pandemic will allow introducing action protocols for minimising negative health effects.

People use a variety of coping strategies (Kasi et al., 2007), both in situations of acute stress (e.g., personal or social emergencies), and in chronic ones (e.g., illnesses), and they tend to have their own style that they apply in different circumstances (Kasi, 2012). Lazarus and Folkman (1984) have reported two kinds of coping strategies, one focusing on the problem and designed to resolve it, and the other focusing on emotions with a view to re-establishing an affective equilibrium. Some coping strategies may be functional in the short term, reducing the stressor's impact, although they may become dysfunctional over the long term, compromising people's quality of life, mental health, and psychological wellbeing (Wahl et al., 1999). Active coping strategies have therefore been positively related to affective states and psychological wellbeing, such as positive reappraisal and coping centred on problem-solving; whereas passive coping strategies, such as negative self-focus, have been related to negative affective states (Espinosa et al., 2009).

When is a coping strategy effective? According to the Resource-Congruence Model of Coping (Wong et al., 2006), efficacy depends on the congruence between the type of strategy and the situation, whereby if the strategy used increases the control over the situation (congruence), it will be effective at reducing stress levels. For example, within the field of hospital care, where high levels of post-traumatic stress disorder (PTSD) have been recorded among healthcare staff (Baysak et al., 2019), a close relationship has been reported between the level of stress and styles of coping among both nurses (Li et al., 2017) and doctors, with significant differences between genders, whereby compared to men women tend to use negative long-term coping strategies, specifically avoidance, rumination and resignation (Sand et al., 2016). Although in the short-term these strategies may reduce the level of stress, in the long-term they would be incongruent because they do not reinforce con- trol over the situation. In other circumstances, such as natural disasters, the most widely used strategy by those without PTSD is active coping, while passive, religious coping or the use of substances are the prevailing strategies among people with PTSD (Baral \& Bhagawati, 2019; Mesidor \& Sly, 2019). An incongruence is once again observed between these strategies and control of the situation.

These studies report that coping is a dynamic process for adapting to situations that require deploying cognitive and behavioural resources, whereby the exposure to trauma alters the coping process (Piccardi et al., 2016), rendering its study important in specific situations. Knowing which coping strategies are the ones that generate the least control in certain situations would undoubtedly enable introducing protection mechanisms in those people that are more vulnerable to stress. Much more so if the situation that causes stress in people is uncommon and there are scarcely any studies on its psychological consequences, as in the case of the COVID-19 pandemic. Particularly significant are the gender differences in these situations, as the same stressors may impact on men and women differently (Frey, 2000). This is possible because men and women assess threatening situations in different ways, and also because of their prevailing approach to coping. Generally speaking, men tend to cope by focusing on the issue, whereas women focus on the emotion, with a tendency to seek outside help (Matud, 2004; Tamres et al., 2002). In other words, women tend to use strategies that are designed more to modify their emotions in a stressful situation, while men seek to tackle the problem (Endler \& Parker, 1990; Matud, 2004; Ptacek et al., 1994). Although, other factors such as level of self-compassion could explain part of the differences ( $\mathrm{Li}$ et al.,2021). This might explain the greater prevalence of stress, anxiety and depression among women (Matud, 2004; Mazure \& Maciejewski, 2003; Meléndez et al., 2012; Kuehner, 2003; Mezulis et al., 2002). Women experience and express emotion more often than men, using communication and empathy as a way of managing the emotional consequences of a threatening situation. Men tend more to control and supress their emotions (Yeh et al., 2009). Men's strategies will tend to be more instrumental and hands-on, focusing on solving the problem, whereas women will use emotion-based strategies to adapt their behaviour (Ptacek et al., 1992; Vingerhoets \& Van Heck, 1990). Differences can be found between the genders even in the early stages of development (Rose \& Rudolph, 2006). Males do so directly or use denial, whereas women respond emotionally with greater social support (Tamres et al., 2002). Moreover, men tend to control their emotional states through behavioural more than 
cognitive avoidance, while women use both strategies with a similar frequency (Kirchner et al., 2008).

We may infer from this that there is a need to study the psychological impact on people in situations of emergency, with a view to implementing strategies that reduce their effects on individuals' physical and psychological wellbeing (Wang et al., 2020). Our research purpose here is therefore to analyse the relationship between coping strategies and levels of anxiety and depression in a Mexican cohort during the COVID-19 pandemic, paying particular attention to gender differences. The following hypotheses were formulated: $\mathrm{H}_{1}$ : A high percentage of the cohort records moderate and severe levels of anxiety and depression $(>30 \%) ; \mathrm{H}_{2}$ : Women record higher levels of anxiety, depression and perceived changes in habits than men. $\mathrm{H}_{3}$ : Women score higher than men in passive coping strategies related to emotional control. Specifically, women are expected to record higher scores in the questionnaire's dimensions for rating their coping with stress that are related to inaction: Negative Self-Focus NST; Open Emotional Expression OEE; Avoidance, AVD; and Religion, RLG; $\mathrm{H}_{4}$ : Passive strategies (NST, OEE, AVD, RLG) are the ones that to a greater extent predict people's levels of anxiety and depression, with the predictive capacity being higher among women.

\section{Method}

\section{Participants}

The sample consisted of 747 mexican subjects aged between 18 and $69(M=25.03, S D=8.95)$, who participated voluntarily, without receiving any type of compensation or pressure. All the participants read and signed the informed consent form (Table 1).

Table 1. Descriptive analysis of the sample

\begin{tabular}{lllll}
\hline Gender (\%) & Female (54.4) & Male (45.6) & & Studying \& Working (6.0) \\
Occupation (\%) & None (2.1) & Studying (57.4) & Working (34.4\%) & Divorced (1.5) \\
Partnership status (\%) & Single (83.8) & Married (8.7) & Civil Partnership (6.0) & \\
Children (\%) & Yes (13.8) & No (86.2) & & \\
\hline
\end{tabular}

\section{Procedure}

Beside the participants' informed consent, the full instrument contained the two questionnaires and the two inventories described in the following section. It was administered through the application Google Form. The snowball sampling technique was used to ensure the cohort was large enough and involved students in their first years, who were studying psychology at the Zaragoza Faculty of Higher Studies (National Autonomous University of Mexico). This non-probabilistic sampling technique is used to identify potential subjects in studies in which they are not easy to find. The instrument was administered between 13/05/2020 and 28/05/2020, at a time when Mexico was at a critical stage in the COVID-19 pandemic. The first step involved the informed consent and the questionnaire on sociodemographic data-habits, which was followed by the questionnaire on coping with stress, and finally, the anxiety and depression inventories.

As the work contained in this document did not involve experimenting on humans or animals, it is redundant to refer to the World Medical Association's Code of Ethics on Human Experimentation (Declaration of Helsinki). The manuscript complies with the Recommenda- tions for the Conduct, Reporting, Editing and Publication of Scholarly Work in Medical Journals, and seeks the inclusion of representative human populations (sex, age, and ethnicity) according to those recommendations. Our aim has been to use the terms sex and gender correctly. We have also used inclusive language.

\section{Instruments}

Sociodemographic-Habits Questionnaire (CO$V I D-19)$. Ad-hoc questionnaire for recording the participants' sociodemographic data and habits during the initial stages of the COVID-19 pandemic in Mexico. Sociodemographic data: age, gender, occupation, partnership status, children. Data on habits: How many hours do you spend a day watching TV or looking at a mobile device? (TV.Mobile); How many hours do you spend a day using social networks? (Social networks); How many hours do sleep every day? (fewer than 3, from 3 to 5 , from 5 to 8 , more than 8) (Sleeping); How often do you eat every day? (Eating); Do you do any physical activity? (Physical activity); On a scale from 1 (very little) to 10 (a lot), to what extent have your habits changed during COVID-19? (Change in habits). 
The Stress Coping Questionnaire (SCQ) (Sandín \& Chorot, 2003). It has seven coping dimensions that record low correlations with each other, whereby the coping styles can be assessed independently. Focused on solving the problem (FSP); Negative Self-Targeting or Self-Criticism (NST); Positive Reappraisal (PR); Open Emotional Expression (OEE); Avoidance (AVD); Seeking Social Support (SSS); and Religion (RLG). In the present investigation the version for Mexican population (González \& Laredo, 2007) was used, with a Cronbach's alpha ranging between .64 and .87 in the seven types of coping. The questionnaire's analysis of reliability in the sample of the present study recorded a Cronbach's Alpha that ranged between .69 and .91. The questionnaire is designed to assess coping as a trait, but as its authors note (Sandín \& Chorot, 2003), by modifying the instructions it can be used for assessing coping with specific situations or moments of stress. This research asked participants to complete the questionnaire taking into account the current situation involving COVID-19.

Beck Anxiety Inventory (BAI) (Beck et al., 1988). In the present investigation, the version for Mexican population (Robles et al., 2001) was used, which presented a Cronbach's Alfa of .83. The questionnaire's reliability analysis in the sample of the present study was Cronbach's Alfa $=.93$. It is a self-report measure with 21 items that rate the symptoms of anxiety in the week before it is administered. The scores for the severity of the symptoms range from 0 to 63 . The inventory allows establishing categories based on the scores obtained: minimal (0-7), slight (8-15), moderate (16-25), and severe (26-63).

Beck Depression Inventory (BDI-IA) (Beck \& Steer, 1993; Spanish version by Jurado et al., 1998). In the present investigation the version for Mexican population
(Jurado et al., 1998) was used, which presented a Cronbach's Alfa of .87. The questionnaire's reliability analysis in the sample of the present study was Cronbach's Alfa $=.92$. It is a self-report measure with 21 items referring to depressive symptoms in the week before it is administered, with four answer options. The scores for the severity of symptoms range from 0 to 63 . The inventory allows establishing categories based on the scores obtained: minimal (0-13), slight (14-19), moderate (20-28), and severe (29-63).

\section{Statistical analyses}

$\mathrm{A} \mathrm{Chi}^{2}$ analysis was performed to discover the sample's distribution in the different categories of anxiety and depression (verification of $\mathrm{H}_{1}$ ). An analysis was then conducted of the gender differences in all the variables analysed through a Student t-test (Cohen's d) or $\mathrm{Chi}^{2}$ (Cramer's V) (verification of $\mathrm{H}_{2}$ and $\mathrm{H}_{3}$ ). Stepwise regression analyses were also conducted (men, women, total sample), with the dependent variables being anxiety and depression, and with coping strategies as the predictor variables (verification of $\mathrm{H}_{4}$ ). Finally, an analysis was conducted of the differences between the categories of anxiety and depression (minimal, slight, moderate, severe) in the scores obtained in the coping strategies that were part of the regression model, controlling for age as the covariable (MANCOVA) (verification of $\mathrm{H}_{4}$ ).

\section{Results}

Analysis of the distribution of the sample in the categories of anxiety and depression (Verification of $\mathrm{H}_{1}$ )

Table 2. Distribution by gender in the categories of anxiety and depression.

\begin{tabular}{|c|c|c|c|c|c|c|}
\hline \multirow[b]{2}{*}{$N=747$} & \multicolumn{4}{|c|}{ Anxiety } & \multirow[t]{2}{*}{$C h i^{2}$} & \multirow[t]{2}{*}{ V } \\
\hline & $\begin{array}{l}\text { Minimal } \\
(n=206)\end{array}$ & $\begin{array}{c}\text { Slight } \\
(n=202)\end{array}$ & $\begin{array}{l}\text { Moderate } \\
(n=173)\end{array}$ & $\begin{array}{c}\text { Severe } \\
(n=166)\end{array}$ & & \\
\hline Men (\%) & 59.22 & 53.50 & 36.40 & 28.90 & $44.95^{*}$ & .25 \\
\hline \multirow[t]{2}{*}{ Women (\%) } & 40.78 & 46.50 & 63.60 & 71.10 & & \\
\hline & \multicolumn{4}{|c|}{ Depression } & $C h i^{2}$ & $V$ \\
\hline$N=747$ & $\begin{array}{l}\text { Minimal } \\
(n=384)\end{array}$ & $\begin{array}{c}\text { Slight } \\
(\mathrm{n}=122)\end{array}$ & $\begin{array}{l}\text { Moderate } \\
(n=144)\end{array}$ & $\begin{array}{l}\text { Severe } \\
(n=97)\end{array}$ & & \\
\hline Men $(\%)$ & 51.80 & 47.50 & 38.90 & 28.87 & $19.23 *$ & .16 \\
\hline Women $(\%)$ & 48.20 & 52.50 & 61.10 & 71.13 & & \\
\hline
\end{tabular}

$* p<.0001$. 
Analysis of gender differences (verification of $\mathrm{H}_{2}$ and $\mathrm{H}_{3}$ )

Table 3. Analysis of gender differences in all the variables

\begin{tabular}{|c|c|c|c|c|}
\hline & $\begin{array}{c}\text { Men } \\
(N=341)\end{array}$ & $\begin{array}{l}\text { Women } \\
(N=406)\end{array}$ & $t / C h i^{2}$ & $d / V$ \\
\hline Age & $25.26(9.56)$ & $24.83(8.42)$ & 0.66 & 0.05 \\
\hline Occupation (Studying) & $56.30 \%$ & $58.37 \%$ & 2.66 & 0.06 \\
\hline Partnership Status (Single) & $84.75 \%$ & $83.00 \%$ & 1.07 & 0.04 \\
\hline Children (Yes) & $9.97 \%$ & $17.00 \%$ & $7.69 * *$ & 0.10 \\
\hline Hours TV.Mobile & $7.40(3.78)$ & $7.69(4.10)$ & -1.01 & 0.07 \\
\hline Hours social networks & $2.77(0.94)$ & $2.87(0.94)$ & -1.57 & 0.11 \\
\hline Sleeping habits $(<5 \mathrm{~h})$ & $14.08 \%$ & $16.00 \%$ & 3.53 & 0.07 \\
\hline Eating habits & $3.30(0.91)$ & $3.13(0.88)$ & $2.60 *$ & 0.20 \\
\hline Physical activity (Yes) & $66.66 \%$ & $58.62 \%$ & $4.98 *$ & 0.08 \\
\hline Change in habits & $6.30(2.38)$ & $6.92(2.45)$ & $-3.48 * *$ & 0.26 \\
\hline Anxiety & $13.66(11.60)$ & $19.49(12.94)$ & $-6.49 * * *$ & 0.47 \\
\hline Depression & $13.07(10.58)$ & $17.43(12.70)$ & $-5.12 * * *$ & 0.37 \\
\hline FSP & $13.55(5.54)$ & $12.63(5.32)$ & $2.33 *$ & 0.17 \\
\hline NST & $8.16(4.37)$ & $9.04(4.46)$ & $-2.71 * *$ & 0.20 \\
\hline PR & $15.40(4.16)$ & $15.16(4.37)$ & 0.77 & 0.06 \\
\hline OEE & $7.33(5.08)$ & $8.79(5.40)$ & $-3.78 * * *$ & 0.28 \\
\hline AVD & $13.18(4.97)$ & $14.06(5.06)$ & $-2.40 *$ & 0.18 \\
\hline SSS & $9.35(6.54)$ & $10.26(6.89)$ & -1.84 & 0.14 \\
\hline RLG & $2.41(4.14)$ & $3.50(4.88)$ & $-3.33 * *$ & 0.24 \\
\hline
\end{tabular}

Note. FSP = Focused on solving the problem; NST = Negative Self-Targeting or Self-Criticism; PR = Positive Reappraisal; OEE = Open Emotional Expression; AVD = Avoidance; SSS = Seeking Social Support; RLG = Religion. $*^{*}<.05 ; * * p<.01 ; * * p<.0001$.

Regression analysis (verification of $\mathrm{H}_{4}$ )

Table 4. Stepwise regression analysis of the different coping styles or strategies (predictor variables) on Anxiety and Depression (criterion variables). Only the final models separated by gender are shown, as well as the joint model.

\begin{tabular}{|c|c|c|c|c|c|c|}
\hline \multicolumn{7}{|l|}{$\operatorname{Men}(N=341)$} \\
\hline Anxiety & Beta & $S E$ & beta stand. & $t$ & $L L$ & $H L$ \\
\hline NST & .810 & .13 & .31 & $6.18 * *$ & .552 & 1.068 \\
\hline OEE & 633 & .11 & .28 & $5.60 * *$ & .411 & .856 \\
\hline PR & -.566 & .13 & -.20 & $-4.30 * *$ & -.826 & -.307 \\
\hline \multicolumn{7}{|c|}{$R=.506 \mathrm{R}^{2}=.256 S E=10.05 \quad F=38.69 p<.0001$} \\
\hline \multicolumn{7}{|l|}{ Depression } \\
\hline NST & .767 & .12 & .32 & $6.53 * *$ & .535 & .998 \\
\hline OEE & .602 & .10 & .29 & $5.82 * *$ & .398 & .806 \\
\hline PR & -.535 & .12 & -.21 & $-4.47 * *$ & -.770 & -.299 \\
\hline RLG & -.345 & .12 & -.14 & $-2.82 *$ & -.586 & -.104 \\
\hline$R=.532 \mathrm{R}^{2}=.283$ & $S E=9.01 \quad F=33.21$ & $p<.0$ & & & & \\
\hline
\end{tabular}




\begin{tabular}{|c|c|c|c|c|c|c|c|}
\hline \multicolumn{8}{|c|}{ Women $(\mathrm{N}=406)$} \\
\hline \multicolumn{2}{|c|}{ Anxiety } & Beta & $S E$ & beta stand. & $t$ & $L L$ & $H L$ \\
\hline \multicolumn{2}{|l|}{ NST } & 1.08 & .13 & .37 & $8.39 * *$ & .823 & 1.327 \\
\hline \multicolumn{2}{|l|}{ OEE } & .687 & .11 & .28 & $6.39 * *$ & .469 & .886 \\
\hline \multicolumn{2}{|l|}{ RLG } & -.393 & .11 & -.15 & $-3.60 * *$ & -.607 & -.178 \\
\hline$R=.570$ & $\mathrm{R}^{2}=.325$ & $S E=10.67$ & $F=64.46$ & $p<.0001$ & & & \\
\hline \multicolumn{8}{|c|}{ Depression } \\
\hline \multicolumn{2}{|c|}{ NST } & 1.19 & .12 & .42 & $9.76^{* *}$ & .953 & 1.434 \\
\hline \multicolumn{2}{|l|}{ RLG } & -.44 & .12 & -.17 & $-4.11 * *$ & -.649 & -.229 \\
\hline \multicolumn{2}{|l|}{ OEE } & .52 & .10 & .22 & $5.10^{* *}$ & .318 & .715 \\
\hline \multicolumn{2}{|l|}{ PR } & -.52 & .12 & -.18 & $-4.36^{* *}$ & -.755 & -.286 \\
\hline & $\mathrm{R}^{2}=.363$ & $S E=10.18$ & $F=57.25$ & $p<.0001$ & & & \\
\hline \multicolumn{8}{|c|}{$\frac{K=.003}{\text { Total }(N=747)}$} \\
\hline \multicolumn{2}{|c|}{ Anxiety } & Beta & $S E$ & beta stand. & $t$ & $L L$ & $H L$ \\
\hline \multicolumn{2}{|l|}{ NST } & .996 & .09 & .35 & $10.70 * *$ & .813 & 1.179 \\
\hline \multicolumn{2}{|l|}{ OEE } & .729 & .08 & .31 & $9.33 * *$ & .576 & .882 \\
\hline \multicolumn{2}{|l|}{ PR } & -.384 & .09 & -.13 & $-4.15^{*}$ & -.566 & -.203 \\
\hline \multicolumn{2}{|l|}{ RLG } & -.240 & .09 & -09 & $-2.78^{*}$ & -.409 & -.070 \\
\hline$R=.555$ & $\mathrm{R}^{2}=.308$ & $S E=10.57$ & $F=82.45$ & $p<.0001$ & & & \\
\hline \multicolumn{8}{|c|}{ Depression } \\
\hline \multicolumn{2}{|l|}{ NST } & 1.02 & .09 & .38 & $11.81 * *$ & .848 & 1.186 \\
\hline \multicolumn{2}{|l|}{ OEE } & .599 & .07 & .26 & $8.28 * *$ & .457 & .741 \\
\hline \multicolumn{2}{|l|}{ PR } & -.536 & .09 & -.19 & $-6.26 * *$ & -.705 & -.368 \\
\hline \multicolumn{2}{|l|}{ RLG } & -.367 & .08 & -.14 & $-4.59 * *$ & -.523 & -.210 \\
\hline$R=.579$ & $\mathrm{R}^{2}=.335$ & $S E=9.78$ & $F=93.61$ & $p<.0001$ & & & \\
\hline
\end{tabular}

Note $:$ FSP $=$ Focused on solving the problem; NST = Negative Self-Targeting or Self-Criticism; PR = Positive Reappraisal; OEE = Open Emotional Expression; AVD = Avoidance; SSS = Seeking Social Support; RLG $=$ Religion. ${ }^{*} p<.01 ; * * p<.0001$.

The final regression model for anxiety among women explained $32.5 \%$ of the variance, including the strategies of NST $\left(R^{2}=0.229\right)$, OEE $\left(R^{2}=0.074\right)$ and religion $\left(R^{2}\right.$ $=0.022$ ). In turn, the final regression model for depression explained $36.3 \%$ of the variance, including the strategies of NST $\left(R^{2}=.244\right)$, religion $\left(R^{2}=.050\right)$, OEE $\left(R^{2}\right.$ $=.039)$ and $\mathrm{P} R\left(R^{2}=.030\right)$. By contrast, the final regression model for anxiety among men explained $25.0 \%$ of the variance, including NST $\left(R^{2}=0.154\right) \operatorname{OEE}\left(R^{2}=\right.$ $0.057)$ and PR $\left(R^{2}=0.039\right)$. The final regression model for depression explained $27.5 \%$ of the variance, including the strategies of NST $\left(R^{2}=0.161\right)$, OEE $\left(R^{2}=\right.$ $0.048), \mathrm{PR}\left(R^{2}=0.051\right)$ and religion $\left(R^{2}=0.015\right)$. Lastly, the final regression model for anxiety among both men and women (total) explained $30.8 \%$ of the variance, including the strategies of NST $\left(R^{2}=0.204\right)$, OEE $\left(R^{2}=\right.$ $0.075)$, PR $\left(R^{2}=0.021\right)$ and religion $\left(R^{2}=.008\right)$. The final regression model for depression among men and wo- men (total) explained $33.5 \%$ of the variance, including the strategies of NST $\left(R^{2}=0.215\right)$, OEE $\left(R^{2}=0.054\right)$, PR $\left(R^{2}=.047\right)$ and religion $\left(R^{2}=0.019\right)$.

\section{Analysis of the differences in coping according to the categories of anxiety and depression}

Considering all the variables together, the MANCOVA revealed the significant effects of the categories of anxiety $\left(\lambda=.72, F_{(4,12)}=21.32, p<.0001, n_{p}^{2}=0.10\right)$. Individually, the variables had significant effects on NST $\left(F_{(3,742)}=54.92, p<.0001, n_{p}^{2}=0.18\right), \operatorname{OEE}\left(F_{(3,742)}=\right.$ 41.67, $\left.p<.0001, n_{p}^{2}=0.14\right)$, PR $\left(F_{(3,742)}=6.22, p<\right.$ $\left..0001, n_{p}{ }^{2}=0.03\right)$, but not on religion $\left(F_{(3,742)}=0.72, p=\right.$ $.542, n_{p}^{2}=0.00$ ) (see Bonferroni analysis in Table 5 and Figure 1).

Considering all the variables together, the MANCOVA revealed the significant effects of the categories of 
depression $\left(\lambda=0.71, F_{(4,12)}=22.92, p<.0001, n_{p}{ }^{2}=\right.$ $0.11)$. Individually, the variables had significant effects on NST $\left(F_{(3,742)}=60.76, p<.0001, n_{p}^{2}=0.20\right)$, OEE $\left(F_{(3,742)}=30.31, p<.0001, n_{p}^{2}=0.11\right), \operatorname{PR}\left(F_{(3,742)}=9.99\right.$, $\left.p<.0001, n_{p}^{2}=0.04\right)$, and religion $\left(F_{(3,742)}=2.84, p=\right.$ $.037, n_{p}^{2}=0.01$ ) (see Bonferroni analysis in Table 5 and Figure 1).

Table 5. Bonferroni analysis of the variables studied $(N=747)$

\begin{tabular}{|c|c|c|c|c|c|c|c|}
\hline \multicolumn{3}{|l|}{ Anxiety } & \multicolumn{5}{|c|}{$C I(95 \%)$} \\
\hline & & & $M_{(I-J)}$ & $S E$ & $p$ & $L L$ & $H L$ \\
\hline \multirow[t]{6}{*}{ NST } & Minimal & Slight & -1.42 & 0.40 & .002 & -2.47 & -0.37 \\
\hline & Minimal & Moderate & -3.04 & 0.42 & $<.0001$ & -4.15 & -1.94 \\
\hline & Minimal & Severe & -5.18 & 0.42 & $<.0001$ & -6.30 & -4.06 \\
\hline & Slight & Moderate & -1.62 & 0.42 & .001 & -2.72 & -0.53 \\
\hline & Slight & Severe & -3.76 & 0.42 & $<.0001$ & -4.87 & -2.65 \\
\hline & Moderate & Severe & -2.14 & 0.43 & $<.0001$ & -3.28 & -0.99 \\
\hline \multirow[t]{6}{*}{ OEE } & Minimal & Slight & -1.92 & 0.48 & $<.0001$ & -3.21 & -0.64 \\
\hline & Minimal & Moderate & -3.86 & 0.51 & $<.0001$ & -5.21 & -2.51 \\
\hline & Minimal & Severe & -5.42 & 0.52 & $<.0001$ & -6.78 & -4.05 \\
\hline & Slight & Moderate & -1.94 & 0.51 & .001 & -3.28 & -0.60 \\
\hline & Slight & Severe & -3.49 & 0.51 & $<.0001$ & -4.85 & -2.14 \\
\hline & Moderate & Severe & -1.56 & 0.53 & .020 & -2.96 & -0.16 \\
\hline \multirow[t]{3}{*}{ PR } & Minimal & Severe & 1.24 & 0.45 & .033 & 0.06 & 2.42 \\
\hline & Slight & Severe & 1.67 & 0.44 & .001 & 0.49 & 2.84 \\
\hline & Moderate & Severe & 1.74 & 0.46 & .001 & 0.52 & 2.95 \\
\hline \multirow[t]{2}{*}{ Depression } & & & \multicolumn{5}{|c|}{ CI (95\%) } \\
\hline & & & $M_{(I-J)}$ & $S E$ & $p$ & $L L$ & $H L$ \\
\hline \multirow[t]{6}{*}{ NST } & Minimal & Slight & -1.61 & 0.42 & .001 & -2.71 & -0.51 \\
\hline & Minimal & Moderate & -3.20 & 0.39 & $<.0001$ & -4.23 & -2.17 \\
\hline & Minimal & Severe & -5.65 & 0.46 & $<.0001$ & -6.86 & -4.45 \\
\hline & Slight & Moderate & -1.59 & 0.49 & .007 & -2.88 & -0.31 \\
\hline & Slight & Severe & -4.05 & 0.54 & $<.0001$ & -5.47 & -2.62 \\
\hline & Moderate & Severe & -2.43 & 0.52 & $<.0001$ & -3.81 & -1.05 \\
\hline \multirow[t]{4}{*}{ OEE } & Minima & Moderate & -2.76 & 0.49 & $<.0001$ & -4.06 & -1.47 \\
\hline & Minimal & Severe & -5.06 & 0.57 & $<.0001$ & -6.57 & -3.54 \\
\hline & Slight & Severe & -3.80 & 0.68 & $<.0001$ & -5.59 & -2.01 \\
\hline & Moderate & Severe & -2.29 & 0.65 & .003 & -4.02 & -0.56 \\
\hline \multirow[t]{3}{*}{ PR } & Minimal & Moderate & 1.21 & 0.41 & .021 & 0.12 & 2.30 \\
\hline & Minimal & Severe & 2.48 & 0.48 & $<.0001$ & 1.20 & 3.75 \\
\hline & Slight & Severe & 2.10 & 0.57 & .001 & 0.60 & 3.61 \\
\hline
\end{tabular}

Note . NST = Negative Self-Focus; OEE = Open Emotional Expression; RLG = Religion; PR = Positive Reappraisal Coping; $\mathrm{CI}=$ confidence interval; $\mathrm{LL}=$ lower level; $\mathrm{HL}=$ higher level. 

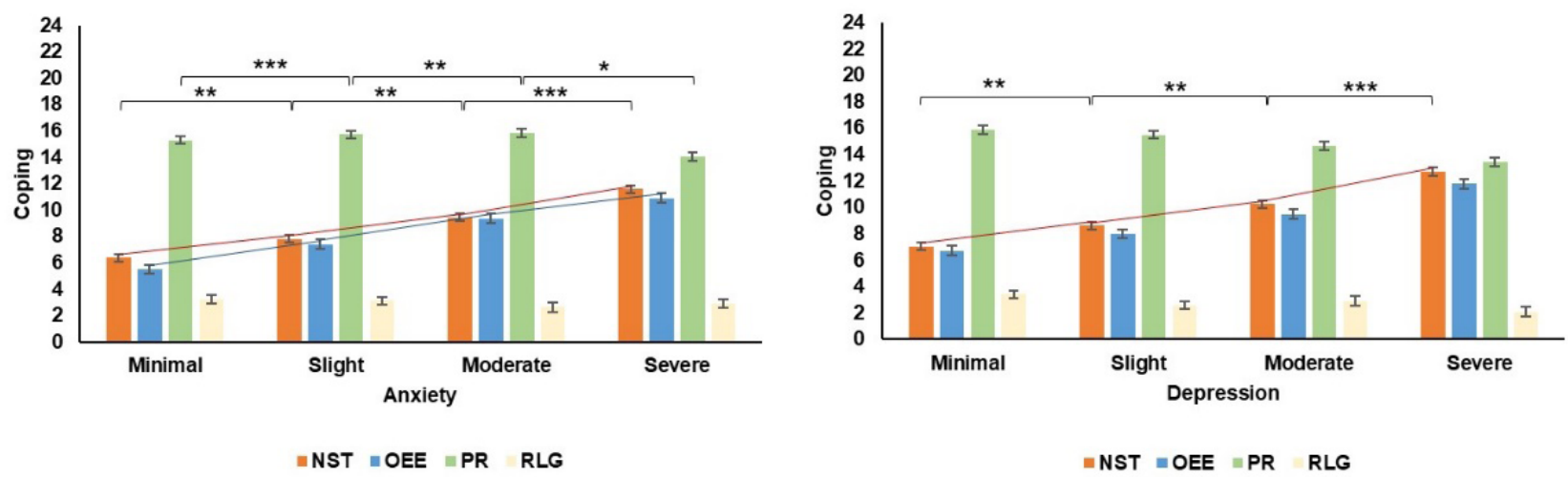

Figure 1. Analysis of the progression of levels of coping through the categories of anxiety and depression. The bars depict standard errors. Lines depict significant progression between categories $* p<.05 ; * * p<.001 ; * * * p<.0001$

\section{Discussion}

The purpose of this research was to analyse the relationship between coping strategies and levels of anxiety and depression among a Mexican cohort during the COVID-19 pandemic. The sample consisted mainly of individuals that were students $(57.4 \%)$, single $(83.8 \%)$ and without children $(86.2 \%)$, with an average age of 25.03 $(S D=8.95) ; 45.38 \%$ and $32.13 \%$ of the sample had moderate/severe levels of anxiety and depression, respectively $\left(\mathrm{H}_{1}\right.$ is confirmed). In addition, women recorded higher levels than men in both anxiety $(p<.0001)$ and depression $(p<.0001)$, with significant differences $(p<$ $.0001)$ in the percentage of men and women with moderate anxiety (36.40/63.60) and serious anxiety $(28.90 / 71.10)$; as well as in moderate depression $(28.90 / 61.10)$ and serious depression $(29.20 / 70.80)\left(\mathrm{H}_{2}\right.$ is confirmed). Furthermore, women perceive greater changes in their habits during the pandemic than men ( $p$ $=.001$ ). These figures are consistent with those issued by the WHO, whereby women are more prone to suffer from anxiety and depression (WHO, 2020b), which in all likelihood have increased during the COVID-19 pandemic.

There are marked gender differences between the strategies women (vs. men) use to cope with COVID-19. Women scored higher in passive coping strategies, such as $\operatorname{NST}(p=.007, d=0.20)$, OEE $(p<.0001, d=.28)$, avoidance $(p=.017, d=0.18)$ and religion $(p=.001, d$ $=0.24)$; while men scored higher in active coping strategies such as FSP ( $p=.020, d=0.17)\left(\mathrm{H}_{3}\right.$ is confirmed). The regression analyses showed that passive coping strategies were the ones that predicted the variance more accurately both in anxiety (30.8\%) and in depression $(33.5 \%)\left(\mathrm{H}_{4}\right.$ is confirmed). The NST strategy was the one that had the greatest predictive capacity over anxiety
(20.4\%) and depression (21.5\%), among both men and women (see Table 4), and it is also the coping strategy that allowed characterising the categories of anxiety and depression; in other words, as Graphic 1 shows, it was the only one that increases significantly in the subjects when passing from one category of lower anxiety and depression to another higher one. The explanation for this is that this style of coping involves defencelessness, a feeling of guilt, and the belief that things tend to turn out badly. It is precisely in a situation such as the COVID-19 pandemic that people feel defenceless and unable to control the situation, aspects that may exacerbate levels of anxiety and depression in individuals that use a type of coping that is incongruent with control of the situation.

These results are significant, because they mark out the path to be followed for reducing people's levels of anxiety and depression during situations of emergency of this kind. However, other variables should also be taken into account to fully explain the effects of pandemic stress on mental health (e.g., Li et al., 2001). Based on the approach that understands coping to be a process (Lazarus \& Folkman, 1984), a clear contextual dependence is assumed, with its being understood that a subject's response is determined by the interplay between external circumstances and personal dispositions. According to this perspective, coping is determined by both the situation and the individual (Torestad et al., 1990). There is nothing new about this approach, although it is particularly important for explaining why the NST strategy is the one that best predicts levels of anxiety and depression. The explanation might lie in the congruence between the type of strategy, type of stressor, and personal dispositions. According to the Resource-Congruence Model of Coping (Wong et al., 2006), having enough resources and making good use of them is vital for ensu- 
ring the coping strategy effectively performs its mission of reducing levels of stress. There are two types of congruence within this model that are important for the coping strategy's efficacy. On the one hand, the situation's appraisal should reflect reality and be based on an objective and rational assessment of available resources and demands. On the other, the chosen strategies should be congruent with the nature of the stressor and the cultural context. This suggests that coping's effectiveness depends on strategies that are congruent with control over the stressful situation. According to this viewpoint, those strategies that are less congruent with the controllability of the situation of pandemic are precisely those that coincide with the psychological effects that this situation generates in people, such as NST, which has also been consistently related to quality of life (Contreras et al., 2007).

In sum, the NST strategy in a pandemic is the one that records the lowest congruence with control of the situation. The necessary tools should be used from the onset of the emergency to permit people to adopt strategies designed to promote their perception of control over the situation, with each government introducing unequivocal rules of behaviour. The ability to cope with situations is one of the key variables for understanding the levels of anxiety and depression prompted by a stressful situation. Along these lines, the scientific literature has found that women use coping strategies that are more focused on emotion, whereas men's strategies deal instead with resolving the problem. Women will therefore be especially vulnerable in these kinds of situations to experiencing high levels of anxiety and depression.

This research has a series of limitations: 1) The nature of the sample does not allow generalising the results (young, student, single and without children); 2) the online format used hinders its laboratory control; 3). This is mainstream research that has been applied at a specific moment in the pandemic (13/05/2020-28/05/2020); nevertheless, the accumulated effect of the days of pandemic that have not been recorded here would have a major influence on people's levels of anxiety and depression that has not been accounted for. Future research should focus on a more detailed analysis of which factors could modulate the change in strategies designed to control the situation, involving longitudinal approaches and broader samples that encompass all age ranges and social types. What's more, the cultural component might also play an important part, as it has been found that cultural values predict certain coping strategies, such as religion and avoidance (Bardi \& Guerra, 2010), which should be studied in future research because they could explain the differences in levels of anxiety and depression across different countries facing similar emergency situations. This would be most relevant, as high levels of stress have a major impact on the decisions made in situation of emergency (Kowalski-Trakofler et al., 2003). An interesting link would therefore be established between culture, coping, levels of stress and the ramifications of situations of emergency, which in the specific case of COVID-19 could be encapsulated in the way people decide to protect themselves, accepting government recommendations to a greater or lesser extent, with very clear implications on the level of contagion and the growing seriousness of the situation of emergency.

\section{Conflict of interest}

All authors have no conflicts of interest to declare

\section{References}

Baral, I. A., \& Bhagawati, K. C. (2019). Post traumatic stress disorder and coping strategies among adult survivors of earthquake, Nepal. BMC Psychiatry, 19, 118. https://doi. org/10.1186/s12888-019-2090-y

Bardi, A., \& Guerra, V. M. (2010). Cultural values predict coping using culture as an individual difference variable in multicultural samples. Journal of Cross-Cultural Psychology, 42(6), 908-927. https://doi.org/10.1177/0022022110381119

Baysak, E., Eroglu, M., Utku, C., \& Kaya, B. (2019). Evaluation of post-traumatic stress disorder, burnout and coping styles in emergency and intensive care unit employees. Klinik Psikiyatri Dergisi-Turkish Journal of Clinical Psychiatry, 22(1), 36-47. https://doi.org/10.5505/kpd.2018.55707

Beck, A. T., \& Steer, R. A. (1993). Beck Depression Inventory. Manual. San Antonio, TX: The Psychological Corporation.

Beck, A., Epstein, N., Brown, G., \& Steer, R. (1988). An inventory for measuring clinical anxiety. Psychometric properties. Journal of Consulting and Clinical Psychology, 56, 893-897. https://doi.org/10.1037//0022-006x.56.6.893

Contreras, F., Esguerra, G., Espinosa, J., y Gómez, V. (2007). Estilos de afrontamiento y calidad de vida en pacientes con insuficiencia renal crónica (IRC) en tratamiento de hemodiálisis. Revista Acta Colombiana de Psicología, 10(2) 169-179.

Endler, N. S., \& Parker, J. D. A. (1990). Multidimensional assessment of coping: A theoretical analysis. Journal of Personality and Social Psychology, 58(5), 844-854. https:// doi.org/10.1037/0022-3514.58.5.844

Espinosa, J. C., Contreras, F. V., y Esguerra, G. A. (2009). Afrontamiento al estrés y modelo psicobiológico de la personalidad en estudiantes universitarios. Revista Diversitas. Perspectivas en Psicología, 5(1), 87-95. https://doi. org/10.15332/s1794-9998.2009.0001.07

Frey, J. (2000). Gender differences in coping styles and coping effectiveness in chronic obstructive pulmonary disease groups. Heart and Lung: The Journal of Acute and Critical Cara, 29(5), 367-377. https://doi.org/10.1067/mhl.2000.108789 
González, M. T. y Laredo, R. (2007). Cuestionario de afrontamiento del estrés (CAE): Validación en una muestra mexicana. Revista de Psicopatología y Psicología Clínica, 12(2), 189198. https://doi.org/10.5944/rppc.vol.12.num.3.2007.4044

Jurado, S., Villegas, M. E., Méndez, L., Rodríguez, F., Loperena, V., y Varela, R. (1998). La estandarización del Inventario de Depresión de Beck para los residentes de la Ciudad de México. Salud Mental, 21(3), 26-31.

Kasi, P. M. (2012). Coping styles in patients with anxiety and depression. International Scholarly Research Network, 128672. https://doi.org/10.5402/2012/128672

Kasi, P. M., Kassi, M., \& Khawar, T. (2007). Excessive work hours of physicians in training: maladaptive coping strategies. PLoS Medicine, 4(9), e205. https://doi.org/10.1371/journal. pmed.0040279

Kirchner, T., Forns, M., Muñoz, D., \& Pereda, N. (2008). Psychometric properties and dimensional structure of the Spanish version of the Coping Responses Inventory-Adult Form. Psicothema, 20(4), 902-909.

Kowalski-Trakofler, K. M., Vaught, C., \& Scharf, T. (2003). Judgment and decision making under stress: An overview for emergency managers. International Journal of Emergency Management 1(3), 278-289. https://doi.org/10.1504/ IJEM.2003.003297

Kuehner, C. (2003). Gender differences in unipolar depression: An update of epidemiological findings and possible explanations. Acta Psychiatrica Scandinavica, 108(3), 163174. https://doi.org/10.1034/j.1600-0447.2003.00204.x

Lazarus, R. S., \& Folkman, S. (1984). Stress appraisal and coping. New York: Springer.

Li, C. X., Meng, Q. B., Yuan, S. Y., Tian, Y. P., Gao, H. B., \& Yao, D Q. (2017). An analysis of coping styles and subjective wellbeing among nurses in the emergency treatment room of grade A tertiary hospitals in a province of China. Chinese Journal of Industrial Hygiene and Occupational Diseases, 35(12), 917920.

cma.j.issn.1001-9391.2017.12.009

Liu, S., Yang, L., Zhang, C., Xiang, Y-T., Liu, Z., Hu, S., \& Zhang, B. (2020). Online mental health services in China during the COVID-19 outbreak. Lancet Psychiatry, 7(4), e17-8. https:// doi.org/10.1016/S2215-0366(20)30077-8

Li, A., Wang, S., Cai, M., Sun, R., \& Liu, X. (2021). Selfcompassion and life-satisfaction among Chinese selfquarantined residents during COVID-19 pandemic: A moderated mediation model of positive coping and gender. Personality and individual differences, 170, 110457. https:// doi.org/10.1016/j.paid.2020.110457

Matud, M. P. (2004). Gender differences in stress and coping styles. Personality and Individual Differences, 37(7), 14011415. https://doi.org/10.1016/j.paid.2004.01.010

Mazure, C. M., \& Maciejewski, P. K. (2003). The interplay of stress, gender and cognitive style in depressive onset. Archives of Women's Mental Health, 6(1), 5-8. https://doi.org/10.1007/ s00737-002-0161-3

Meléndez, J. C., Mayordomo, T., Sancho, P., \& Tomás, J. M. (2012). Coping strategies: Gender differences and development throughout life span. The Spanish Journal of Psychology, 15(3), 1089-1098. https://doi.org/10.5209/rev_ SJOP.2012.v15.n3.39399
Mesidor, J. K., \& Sly, K. F (2019). Religious coping, general coping strategies, perceived social support, PTSD symptoms, resilience, and posttraumatic growth among survivors of the 2010 earthquake in Haiti. Mental Health Religion \& Culture, 22(2), 130-143. https://doi.org/10.1080/13674676.2019.1580 254

Mezulis, A. H., Abramson, L. Y., \& Hyde, J. S. (2002). Domain specificity of gender differences in rumination. Journal of Cognitive Psychotherapy, 16(4), 421-434. https://doi. org/10.1891/jcop.16.4.421.52524

Piccardi, L. Marano, A. Geraci, M. A. Legge, E., \& D'Amico, S. (2016). Differences in coping strategies of preadolescents with and without exposure to the L'Aquila (Central Italy) 2009 earthquake. Epidemiologia \& Prevenzione, 40(2), 53-58. https://doi.org/10.19191/EP16.2S1.P053.049

Ptacek, J. T., Smith, R. E., \& Dodge, K. L. (1994). Gender differences in coping with stress: When stressors and appraisal do not differ. Personality and Social Psychology Bulletin, 20(4), 421-430. https://doi.org/10.1177/0146167294204009

Ptacek, J. T., Smith, R. E., \& Zanas, J. (1992). Gender, appraisal, and coping: A longitudinal analysis. Journal of Personality, 60, 747-770. https://doi.org/10.1111/j.1467-6494.1992. tb00272.x

Robles, R., Varela, R., Jurado, S., y Páez, F. (2001). Versión mexicana del Inventario de Ansiedad de Beck: Propiedades psicométricas. Revista Mexicana de Psicología, 18(2), 211218.

Rose, A. J., \& Rudolph, K. D. (2006). A review of sex differences in peer relationship processes: potential trade-offs for the emotional and behavioral development of girls and boys. Psychological Bulletin, 132(1), 98-131. https://doi. org/10.1037/0033-2909.132.1.98

Sand, M., Hessam, S., Sand, D., Bechara, F. G., Vorstius, C., Bromba, M., ... \& Shiue, I. (2016). Stress-coping styles of 459 emergency care physicians in Germany A pilot study. Der Anaesthesist, 65(11), 841-846. https://doi.org/10.1007/ s00101-016-0228-6

Sandín, B., y Chorot, P. (2003). Cuestionario de afrontamiento del estrés (CAE): Desarrollo y validación preliminar. Revista de Psicopatología y Psicología Clínica, 8(1), 39-54. https://doi. org/10.5944/rppc.vol.8.num.1.2003.3941

Sandín, B., Valiente, R. M., García-Escalera, J., Campagne, D. M., y Chorot, P. (2020). Psychological impact of the COVID-19 pandemic: Negative and positive effects in Spanish population during the mandatory national quarantine. Journal of Psychopathology and Clinical Psychology / Revista de Psicopatología y Psicología Clínica, 25(1), 1e-21e. https:// doi.org/10.5944/rppc.28107

Shigemura, J., Ursano, R. J., Morganstein, J. C., Kurosawa, M., \& Benedek, D. M. (2020). Public responses to the novel 2019 coronavirus (2019-nCoV) in Japan: mental health consequences and target populations. Psychiatry and Clinical Neurosciences, 74(4), 281--282. https://doi.org/10.1111/ pcn. 12988

Tamres, L. K., Janicki, D., \& Helgeson, V. S. (2002). Sex differences in coping behavior: A meta-analytic review and an examination of relative coping. Personality and Social Psychology Review, 6(1), 2-30. https://doi.org/10.1207/ S15327957PSPR0601_1 
Torestad, B., Magnusson, D., \& Oláh, A. (1990). Coping, control, and experience of anxiety: An interactional perspective. Anxiety Research,3(1),1-16.https://doi.org/10.1080/08917779008248737

Vingerhoets, A. J., \& Van Heck, G. L. (1990). Gender, coping and psychosomatic symptoms. Psychological Medicine, 20(1), 125-135. https://doi.org/10.1017/S0033291700013301

Wahl, A., Hanestad, B., Wiklund, I., \& Poum, T. (1999). Coping and quality of life in patients with psoriasis. Quality of Life Research, 8(5), 427-433. https://doi.org/10.1023/a:1008944108101

Wang, C., Pan, R., Wan, X., Tan, Y., Xu, L., Ho, C. S., \& Ho, R. C. (2020). Immediate psychological responses and associated factors during the initial stage of the 2019 coronavirus disease (COVID-19) epidemic among the general population in China. International Journal of Environmental Research Public Health, 17(5), 17-29. https://doi.org/10.3390/ ijerph17051729
Wong, P. T. P., Reker, G. T., \& Peacock, E. (2006). The resourcecongruence model of coping and the development of the Coping Schemas Inventory. In Wong, P. T. P., \& Wong, L. C. J. (Eds.), Handbook of Multicultural perspectives on stress and coping. New York, NY: Springer.

World Health Organization. (2020a). Rolling updates on coronavirus disease (COVID-19). https://www.who.int/ emergencies/diseases/novel-coronavirus-2019/events-asthey-happen

World Health Organization. (2020b). Gender disparities in mental health. WHO. https://www.who.int/mental_health/media/ en/242.pdf?ua=1

Yeh, S. J., Huang, C., Chou, H., \& Wan, T. T. H. (2009). Gender differences in stress and coping among elderly patients on hemodialysis. Sex Roles, 60, 44. https://doi.org/10.1007/ s11199-008-9515-2 
